\title{
ANALISIS HUBUNGAN UMUR DAN PARITAS DENGAN KADAR ALBUMIN URIN PADA IBU HAMIL
}

\author{
Aminah Maya \\ Program Studi DIII Kebidanan STIKes Muhammadiyah Palembang \\ Jalan Jendral Ahmad Yani 13 Ulu Palembang \\ Email: mayachabie@gmail.com
}

\begin{abstract}
Abstrak
Latar Belakang : Masa kehamilan merupakan masa yang rentan terhadap segala macam stress yang dapat berakibat pada terjadinya perubahan fisiologi maupun fungsi metabolik. Tujuan: Penelitian ini bertujuan melihat hubungan antara umur dan paritas dengan kadar albumin urin pada ibu hamil. Metode : Jenis penelitian ini adalah penelitian observasional dengan desain penelitian cross sectional. Sampel penelitian adalah ibu hamil sebanyak 30 orang yang didapatkan dengan menggunakan teknik pengambilan accidental sampling. Variabel independen berupa umur ibu dan paritas dan variabel dependennya adalah kadar albumin urin. Sujek penelitian yang telah bersedia untuk menjadi sampel penelitian mengisi lembar kesediaan menjadi responden dan mengisi kuisioner yang berisi pertanyaan yang berhubungan dengan umur dan paritas ibu. dengan menggunakan kuisioner. Setelah kuisioner dilengkapi, dilakukan pemeriksaan terhadap adar albumin urin ibu hamil oleh petugas dari laboratorium klinik Prodia Palembang. Hasil: Dari hasil uji statistik menggunakan Chi square untuk mengetahui hubungan antara umur ibu dan kadar albumn urin, diperoleh tingkat signifikansi $\rho>0.05$ ( $\rho$ : 0.481), dan untuk mengetahui hubungan antara paritas ibu dan kadar albumin urin, diperoleh tingkat signifikansi $\rho>0.05$ ( $\rho: 0.511)$. Kesimpulan: Hasil penelitian ini menunjukkan bahwa kedua variable yang diteliti pada penelitian ini, yaitu variable umur dan paritas tidak terbukti secara signifikan berhubungan dengan kadar albumin urin pada ibu hamil
\end{abstract}

\section{Kata kunci : umur, paritas dan kadar albumin urin}

\begin{abstract}
Background: The period of pregnancy is a period that is vulnerable to all kinds of stress which can result in changes in physiology and metabolic function. Objective: This study aims to determine the relationship between age and parity with urine albumin levels in pregnant women. Methods: This research was an observational study with a cross sectional study design. The research sample was 30 pregnant women who were obtained using accidental sampling technique. The independent variable is maternal age and parity and the dependent variable is urine albumin level. Research subjects who have been willing to become research samples fill out the willingness to be a respondent and fill out a questionnaire containing questions related to age and maternal parity. by using a questionnaire. After the questionnaire was completed, an examination of the urine albumin content of pregnant women was carried out by officers from the Prodia Palembang clinical laboratory. Results: From the results of statistical tests using Chi square to determine the relationship between maternal age and urine albumn content, a significance level of $\rho>0.05$ ( $\rho: 0.481)$ was obtained, and to determine the relationship between maternal parity and urine albumin levels, a significance level of $\rho>0.05$ was obtained. ( $\rho: 0.511)$. Conclusion: The results of this study indicate that the two variables examined in this study, namely the variable age and parity, were not shown to have a significant relationship with urine albumin levels in pregnant women.
\end{abstract}

Key words: age, parity and urine albumin levels

Jurnal Kesehatan dan Pembangunan, Vol. 11, No. 21, Januari 2021 


\section{PENDAHULUAN}

Masa kehamilan merupakan masa yang rentan terhadap segala macam stress yang dapat berakibat pada terjadinya perubahan fisiologi maupun fungsi metabolik. Proses metabolisme ini meningkatkan penggunaan oksigen dan apabila oksigen yang tersedia tidak digunakan maksimal menyebabkan terbentuknya oxidative stress dan menghasilkan radikal bebas berlebihan yang akhirnya berpengaruh terhadap kelangsungan suatu proses kehamilan dan dapat menyebabkan komplikasi (Casanueva dan Viteri, 2013).

Preeklampsia merupakan komplikasi yang berbahaya dalam kehamilan dan mulai timbul pada pertengahan kehamilan trimester kedua dan sindroma ini ditandai dengan adanya hipertensi, proteinuri dan kelainan sistemik lainnya (Morreti, dkk., 2014; Cunningham, dkk., 2015; Redman and Sargent, 2008). Data yang diperoleh dari Rumah Sakit Muhammadiyah Palembang tiga tahun terakhir terdapat sekitar 282 dari 2500 kasus preeklampsi berat $(11,28 \%)$, kemudian mengalami penurunan pada tahun berikutnya yaitu 270 dari 2830 kasus $(9,54 \%)$ dan kembali meningkat pada tahun berikutnya yaitu 297 dari 2146 kasus (13.83\%) (Utami, 2013).

Preeklampsi/eklampsi adalah timbulnya hipertensi disertai proteinuria dan edema akibat kehamilan setelah usia 20 minggu/segera setelah persalinan. Faktorfaktor predisposisi dari pre-eklampsia yaitu usia, status sosial ekonomi, genetik, komplikasi obstetrik dan kondisi medis yang sudah ada sebelumnya. Eklampsia merupakan kelanjutan dari preeklamsi berat dengan tambahan gejala kejang atau koma. Selama terjadi kejang- kejang dapat terjadi suhu naik mencapai $40^{\circ} \mathrm{C}$, Frekuensi nadi bertambah cepat, dan tekanan darah meningkat (Manuaba 2010).

Faktor-faktor terjadinya pre-klampsia umumnya terjadi pada kehamilan pertama kali, kehamilan diusia remaja dan kehamilan diatas diusia tua, riwayat tekanan darah tinggi yang kronis sebelum kehamilan, riwayat mengalami pre-eklampsia sebelumnya, riwayat pre-eklampsia pada ibu atau saudara perempuan, kegemukan mengandung lebih dari satu orang bayi, riwayat kencing manis, kelainan gagal ginjal (Rukiyah,2010)

Kejadian preeklampsia biasanya pada usia ibu yang ektrim yaitu kurang dari 20 tahun dan lebih 35 tahun keatas dan preeklampsia juga sering dijumpai pada kehamilan pada usia kehamilan 37- 42 minggu. Paritas adalah seorang wanita yang sudah pernah melahirkan bayi yang dapat hidup (Prawirohardjo, 2011). Pada primipara frekuensi preeklampsia lebih tinggi bila dibandingkan dengan multipara terutama pada primipara muda. Wanita yang telah banyak melahirkan $\geq 3$ orang rentan terhadap komplikasi yang serius, bahaya pada masa kehamilan salah satunya adalah preeklampsia dimana pada paritas yang tinggi aliran darah akan menurun keplasenta yang menyebabkan ganguan plasenta sehingga terjadi gangguan pertumbuhan janin karena kekurangan oksigenasi (Prawirohardjo, 2011)

Salah satu gejala yang ditemukan pada penderita pre-eklampsia, eklampsia, gagal ginjal, ISK, DM adalah proteinuria. Proteinuria adalah protein yang disekresi melalui urin lebih dari 30 sampai $150 \mathrm{mg}$ per hari. Proteinuria dapat menjadi penanda adanya penyakit dini pada ginjal. Proteinuria dapat bersifat sementara (intermittent), ortostatik (timbul karena kelebihan aktivitas duduk atau berdiri), dan persisten (selalu ada). Pada proteinuria intermittent, proteinuria akan sembuh jika penyebab teratasi. Pada proteinuria ortostatik, ekskresi proteinuria akan normal ketika pasien berbaring dan akan meningkat ketika pasien duduk atau berdiri. Kejadian ini terjadi pada $2 \%$ sampai $5 \%$ orang muda, tetapi tidak biasa pada orang usia 30

tahun ke atas. Pada proteinuria persisten adalah kegagalan pada glomerulus atau pada tubulus. Jenis yang paling umum terjadi adalah proteinuria glomerular dengan albumin sebagai protein primer. Jenis ini disebabkan oleh peningkatan filtrasi albumin. 
Proteinuria tubular yaitu tidak berfungsinya selsel tubulus untuk menyerap protein pada proses filtrasi (Brants, 2009). Pada masa kehamilan dapat terjadi peningkatan protein (albumin) urin yang mengarah pada kejadian preeklampsi akibat proses apoptosis yang distimulasi oleh berkurangnya oksigenasi plasenta (Levy, 2010).

\section{METODE PENELITIAN}

\section{Jenis Penelitian}

Jenis penelitian ini adalah penelitian observasional dengan desain penelitian cross sectional.

\section{Waktu dan Tempat Penelitian}

Penelitian dilakukan di Rumah Sakit Muhammadiyah Palembang Bulan MaretJuli 2017 untuk pengambilan sampel serta Laboratorium Medik Prodia Palembang untuk pemeriksaan kuantitatif kadar albumin urin pada ibu hamil.

\section{Subjek Penelitian}

Populasi dalam penelitian ini adalah seluruh ibu hamil memeriksakan kehamilananya di Poli Kebidanan Rumah Sakit Muhammadiyah Palembang. Sampel penelitian adalah ibu hamil sebanyak 30 orang yang didapatkan dengan menggunakan teknik pengambilan accidental sampling. Variabel independen berupa umur ibu dan paritas dan variabel dependennya adalah kadar albumin urin

\section{PROSEDUR}

Sujek penelitian yang telah bersedia untuk menjadi sampel penelitian mengisi lembar kesediaan menjadi responden dan mengisi kuisioner yang berisi pertanyaan yang berhubungan dengan umur dan paritas ibu. dengan menggunakan kuisioner. Setelah kuisioner dilengkapi, dilakukan pemeriksaan terhadap adar albumin urin ibu hamil oleh petugas dari laboratorium klinik Prodia Palembang. Hasil pemeriksaan kadar albumni urin kemudian dicatat di lembar observasi untuk kemudian dilakukan analisis terkait hubungan umur, paritas dan kadar albumun urin ibu.
Data, Intrumen, dan Teknik Pengumpulan Data

Data umur ibu dan paritas diperoleh dengan menggunakan kuesioner. Data kadar albumin ibu hamil diperoleh dari hasil pemeriksaan laboratorium dan dituliskan ke dalam lembar observasi.

\section{Teknik Analisis Data}

Analisis univariat digunakan untuk mengetahui distribusi karakteristik responden dan analisis hubungan antar variabel diketahui dengan menggunakan uji chi square

\section{HASIL PENELITIAN DAN PEMBAHASAN \\ Hubungan Umur Ibu dan Kadar Albumun Urin}

Dari hasil penelitian yang dilakukan pada 30 responden, didapatkan hasil sebagai berikut:

Tabel 1.

\section{Hubungan Umur ibu dan Kadar albumin} urin

\begin{tabular}{|c|c|c|c|c|}
\hline \multirow[b]{2}{*}{ Umur } & \multicolumn{2}{|c|}{ Anemia } & \multirow{2}{*}{\multicolumn{2}{|c|}{$\begin{array}{c}\text { P } \\
\text { Total value }\end{array}$}} \\
\hline & $\begin{array}{c}\text { Tidak } \\
\text { normal }\end{array}$ & & & \\
\hline \multirow{2}{*}{$\begin{array}{l}\text { Risiko rendah } \\
\text { Risiko Tinggi }\end{array}$} & 13 & 10 & 23 & \\
\hline & 5 & 2 & 7 & \\
\hline Total & 18 & 12 & 30 & \\
\hline
\end{tabular}

Dari hasil uji statistik menggunakan Chi square untuk mengetahui hubungan antara umur ibu dan kadar albumn urin, diperoleh tingkat signifikansi $\rho>0.05 \quad(\rho: 0.481)$ sehingga dapat disimpulkan bahwa tidak ada hubungan antara umur ibu dengan kadr albumin urin.

\section{Hubungan Paritas dan Kadar Albumin Urin}

Dari hasil penelitian yang dilakukan pada 30 responden, didapatkan hasil sebagai berikut: 
Tabel 2.

Hubungan Paritas ibu dan Kejadian Anemia

\begin{tabular}{|c|c|c|c|c|}
\hline \multirow[b]{2}{*}{ Paritas } & \multicolumn{2}{|c|}{ anemia } & & \multirow[b]{2}{*}{$\begin{array}{c}\mathrm{P} \\
\text { value }\end{array}$} \\
\hline & $\begin{array}{c}\text { tidak } \\
\text { normal }\end{array}$ & normal & Total & \\
\hline Primipara & & 1 & 4 & 0,511 \\
\hline Multipara & 1 & 11 & 26 & \\
\hline Total & 1 & 21 & 34 & \\
\hline
\end{tabular}

Dari hasil uji statistik menggunakan Chi square untuk mengetahui hubungan antara paritas ibu dan kadar albumin urin, diperoleh tingkat signifikansi $\rho>0.05 \quad(\rho: 0.511)$ sehingga dapat disimpulkan bahwa tidak ada hubungan antara paritas ibu dengan kadar albumin urin pada ibu hamil. Hasil penelitian ini menunjukkan bahwa kedua variable yang diteliti pada penelitian ini, yaitu variable umur dan paritas tidak terbukti secara signifikan berhubungan dengan kadar albumin urin pada ibu hamil karena banyak faktor lain yang berpengaruh dengan kadar albumin urin pada ibu hamil, antara lain riwayat penyakit yang diderita, riwayat kehamilan, riwayat antenatal care, usia kehamilan dan pola nutrisi yang belum bisa dikendalikan sehingga menjadi variable penganggu pada penelitian ini. Selain itu, jumlah sampel yang tidak terlalu besar juga menjadi penyebab kurang representatifnya hasil penelitian ini.

a. Riwayat kehamilan

Wanita dengan riwayat preeklampsia pada kehamilan pertamanya memiliki resiko 5 sampai 8 kali untuk mengalami preeklampsia lagi pada kehamilan keduanya. Sebaliknya, wanita dengan preeklampsia keduanya, maka bila ditelusuri ke belakang ia memiliki 7 kali resiko lebih besar untuk memiliki riwayat preeklampsia pada kehamilan pertamanya bila dibandingkan dengan wanita yang tidak mengalami preeklampsia di kehamilan yang kedua (Cunninghan dkk., 2013)

b. Riwayat penyakit yang diderita Faktor tingginya kadar protein urin yang menjadi faktor predisposisi preeklampsia/eklampsia antara lain adalah penyakit diabetes melitus, hipertensi kronik, riwayat kehamilan, riwayat keluarga dengan preeklampsia, dan penyakit vaskuler ginjal (Offord,2012)

c. Riwayat ANC

Hasil penelitian Thapa (2016) 1240 wanita pascamelahirkan diwawancarai. Sebagian besar $(94,6 \%)$ pernah menghadiri setidaknya satu kunjungan ANC; Usia kehamilan rata-rata pada kunjungan ANC pertama adalah 4 bulan. Kunjungan ANC ini berhubungan dengan konseling tentang kalsium dan menerima tablet kalsium untuk dikonsumsi setiap hari sampai melahirkan dan

d. Asupan nutrisi selama kehamilan Faktor makanan diduga juga bisa menyebabkan preeklampsia pada kehamilan. Kekurangan kalsium pada tubuh ibu hamil yang dapat menyebabkan peningkatan tekanan darah yang berujung pada preeklamsia. Kalsium dapat membantu menjaga pembuluh darah dan menjaga tekanan darah tetap normal. Demikian pula, kekurangan protein, protein yang berlebihan, minyak ikan, vitamin D dan faktor makanan lainnya juga berperan sebagai penyebab preeklamsiaa. Obesitas juga disebut-sebut sebagai penyebab lain preeklamsia. Indeks masa tubuh yang tinggi berkaitan dengan diabetes, tekanan darah tinggi serta resistensi insulin, dapat mempengaruhi sistem inflamasi (Feryanto, 2012). 


\section{KESIMPULAN}

Hasil penelitian ini menunjukkan bahwa kedua variable yang diteliti pada penelitian ini, yaitu variable umur dan paritas tidak terbukti secara signifikan berhubungan dengan kadar albumin urin pada ibu hamil

\section{SARAN}

Perlu dilakukan penelitian lebih lanjut dengan menghomogenkan sampel penelitian dari variable pengganggu dan menambah jumlah sampel penelitian dengan jumlah yang lebih besar

\section{UCAPAN TERIMA KASIH}

Penulis mengucapkan terima kasih kepada Kemenristek Dikti yang telah memberi dukungan financial terhadap penelitian ini.

\section{DAFTAR PUSTAKA}

Casanueva, R and Viteri, F.R. 2013. Iron and Oxidative Stress in Pregnancy. J. Nutr. 133:p. 1700S- 1708S

Moretti, M., Phillips, M., Abouzeid, A., Cataneo, R. N., Greenberg, J. 2014. Increased Breath Markers Of Oxidative Stress In Normal Pregnancy And In Preeclampsia. Am J Obstet Gynecol 190, p.1184 - 90

Cunningham, F.G., Leveno, K.J., Bloom, et al. 2015. Williams Obstetrics. 22nd Edition. McGraw-Hill Comp, USA

Redman, C.W., and Sargent, I..L. 2008. Circulating Microparticles in Normal Pregnancy and Pre-Eclampsia. Placenta. 29, p 73-77.

Utami, Debi. 2013. Gambaran Karakteristik ibu Bersalin dengan Preeklampsi Berat di Rumah Sakit Muhammadiyah Palembang Tahun 2013. Jurnal Harapan Bangsa Volume 1 No.2. Desember 2013

Manuaba Ida Ayu Chadranita 2010. Ilmu Kebidanan Penyakit Kandung Dan KB. Jakarta : EGC.

Rukiyah Yeyeh Ai 2010. Asuhan Kebidan Patologi Kebidanan. Jakarta : Trans Info Media.
Prawirohardjo, 2011. Ilmu Kebidanan. Jakarta : Yayasan Bina Pustaka

Levey, Andrew S. dkk. The definition, Classification and Prognosis of chronic kidney disease : a KDIGO Controversies Conference Report. USA: 2010. Diakses pada tanggal 3 Maret 2014.

Brants, Algars. Urine Protein Electrophoresis. Sebia: 2009. Diakses pada tanggal 3 Maret 2014.

Cunningham. 2013. Obstetri Williams. Jakarta : EGC

Offord, 2012. How halmiltons children are strarting out .Outcames of Birth: Canadian Centre for Studies of Children risk.http/www.offordcentre.com

Thapa. 2016. Effect of knowledge and perception on adherence to iron and folate supplementation during pregnancy in Kathmandu, Nepal. J Med Assoc Thail. 2014;97:S67-74

Feryanto A, 2012. Asuhan Kebidanan Patologis. Jakarta: Salemba Medika 